\title{
К ВОПРОСУ О СОВРЕМЕННЫХ ИНТЕГРАЛЬНЫХ (СИНТЕТИЧЕСКИХ) ТИПАХ ПРАВОПОНИМАНИЯ В ЮРИДИЧЕСКОЙ НАУКЕ 1
}

\section{ON THE QUESTION OF MODERN \\ INTEGRAL (SYNTHETIC) TYPES OF LEGAL UNDERSTANDING IN LEGAL SCIENCE}

\section{Z. Kalandarishvili \\ G. Kurenkov}

Summary. In this article, the authors explore modern integral (synthetic) types of legal understanding in legal science. According to the authors, the very existence of a variety of approaches and their types to law is a reflection of the diversity of law as a socio-cultural phenomenon. The variety of manifestations of the legal essence and the need to take them into account in a specific analysis actualizes the problem of choosing between possible approaches and their types to the assessment and study of legal phenomena.

Keywords: law, society, phenomenological type of legal understanding, dialogical type of legal understanding, the concept of realistic positivism.

\author{
Каландаришвили Зураб Нодарович \\ К.ю.н., к.п.н., доцент, Санкт-Петербургский \\ гуманитарный университет профсоюзов \\ zurab.kalandarishvili@yandex.ru \\ Куренков Герасим Алексеевич \\ Аспирант, Санкт-Петербургский гуманитарный \\ университет профсоюзов \\ kurencov.spb@gmail.com
}

Аннотация. В своей статье авторы исследуют современные интегральные (синтетические) типы правопонимания в юридической науке. По мнению авторов, само существование разнообразия подходов и их типов к праву является отражением многоплановости права как социокультурного феномена. Многообразие проявлений правовой сущности и необходимость учета их в конкретном анализе актуализирует проблему выбора между возможными подходами и их типами к оценке и в исследовании правовых явлений.

Ключевые слова: право, общество, феноменологический тип правопонимания, диалогический тип правопонимания, концепция реалистического позитивизма.

ности данного объекта (точнее - о его обобщенном образе, сложившемся в сознании познающего субъекта на основе интеллектуальной интуиции). Заметный вклад в становление и развитие феноменологической концепции права внес в свое время известный философ права Н.Н. Алексеев.

Применение феноменологического метода к праву, пишет В.А. Четвернин, «означает поиск общих правовых понятий, норм и институтов, которые трактуются не только как мыслительные образы, но и как реальные надындивидуальные сущности [3].

Сегодня видным представителем феноменологической школы правопонимания является А.В.Поляков, в трудах которого право характеризуется как специфический феномен, существующий в виде «психосоциокультурной коммуникативной системы» [1].

Соответственно право понимается им как «психо-социо-культурный феномен». 
Коммуникативную концепцию права автор трактует как вариант интегрального подхода к пониманию права, соответствующего постклассической парадигме. При этом, следуя традиции русской правовой школы, он считает необходимым выстраивать интегральную юриспруденцию на базе синтеза индивидуального и социального начал в праве. Проблема соотношения индивидуального и общественного рассматривается им под углом зрения имплицитной (ориентированной на внутреннее, духовное общение) и эксплицитной (нацеленной на внешне взаимопонимание и взаимодействие) коммуникации [2].

Суть отмечаемого им «когнитивного переворота в юриспруденции», совершенного с помощью коммуникативной концепции права может быть сведена к тезису: «Право есть там, где люди убеждены в том, что оно есть». Убеждение в наличии права (то есть признание права) «есть признание неких рамок поведения, то есть определенных прав и обязанностей, связывающих всех членов общества; признание их «объективного» характера, понимание их содержания и порядка реализации». Поскольку признание права «невозможно без опыта права», то право «существует как становящееся право, находящееся в постоянной динамике текстуально-информационного и энергийно-поведенческого взаимообмена». Вся эта сложная «самоорганизующаяся и саморазвивающаяся система» через редукцию комплексности превращается в сознании познающего субъектов в некий набор принципов.

«Право,- полагает автор,- это сама социальная жизнь, взятая в специфическом ракурсе, но определение границ права через редукции комплексности неизбежно ведет к упрощенному и фрагментарному его пониманию». При этом задачу современного правоведения он видит в том, чтобы создать (пусть и путем некоторого упрощения) такую теоретическую модель правовой действительности, в рамках которой «было бы возможно совмещение понимания права с позиций юридической практики (права в жизни) с максимально возможным уровнем научного обобщения, противодействующего его (права) теоретической «фрагментации». Это и есть, по его точки зрения, проблема синтеза формального, ценностного и антропологического аспектов правовой коммуникации» [2].

Диалогический тип правопонимания предлагаемый И.Л. Честновым генетически восходит к социологическому пониманию права. Автор данного типа исходит из того, что идея диалога как «напряжения, обусловленности и взаимоперехода антиномий», отражает дихотомичный характер социальной реальности, построенной в своей основе на антиномиях. Теория диалога, отмечает он, имеет два направления:
1. Философская (экзистенциальная) традиция, делающая акцент на единичном и уникальном;

2. Семиотика, разрабатываемая в рамках структурализма и постструктурализма, которая рассматривает диалог как разновидность коммуникационного процесса, предполагающего «наличие единого кода у субъектов этого процесса, их (субъектов) асимметричность (по крайней мере, не тождественность), переменность направления информационных потоков, а также желание поддерживать коммуникацию» [4].

И.Л. Честнов, в границах своего подхода, большое внимание уделяет исследованию юридизации человеческого бытия, вычленению

закономерностей зарождения и развития социально-правового быта как постоянного диалога между людьми.

Диалогическая школа правопонимания, как мы полагаем, занимается поиском «человеческой» составляющей в праве, под которым понимается структура (правила поведения) и ее реализация (включая практическую и ментальную составляющую) в правовом поведении людей, и «правовых качеств» в человеке, то есть ее концепция строится на «человеческом» измерении права. Главным стержнем этого интегрального типа правопонимания является акцентирование на воспроизводстве, динамике правовой реальности, складывающейся из диалога индивидуального правового действия субъекта и порождаемой им нормой, которая понимается не только как образец юридически значимого поведения, но и ее восприятие в общественном правосознании и реализации в правопорядке. Главным субъектом права, согласно этому типу, является человек и порождаемые им правоотношения, на правовое развитие которого большое влияние оказывает историческая и социокультурная обусловленность социумa.

К типу интегрального (синтетического) подхода правопонимания следует отнести и концепцию реалистического позитивизма Р.А. Ромашова.

Концепция реалистического позитивизма основана на интеграции юридического позитивизма и социологической юриспруденции. В рамках данного типа утверждается, что правом регулятивно-охранительная система будет являться только в том случае, если нормы, из которых данная система состоит, являются общезначимыми и оказывают результативное воздействие на общественные отношения. Восприятие права в контексте реалистического позитивизма предполагает выделение абстрактного и реального права. Аб- 
страктное право представляет собой совокупность норм, в основу систематизации которых положено деление права на публичное позитивное, публичное негативное и частное. Реальное право представлено правом в формально-юридическом и функциональном смысле. Право в формально- юридическом смысле представляет совокупность формальных источников, включающих в себя первичные и основные (законодательные акты); производные (нормативные интерпре- тационные акты); вторичные (международные акты, нормативные договоры и юридические обычаи).

Таким образом, исследуемые нами вышеназванные типы интегрального (синтетического) подхода представляют сегодня очень интересные модели понятия и сущности права, так как они отражают конгломерат лучших воззрений ученых на правовые явления современности.

\section{ЛИТЕРАТУРА}

1. Поляков А.В. Общая теория права: Учебник для вузов. СПб.: Юридический центр Пресс, 2004.

2. Поляков А.В. Российская теоретико-правовая мысль: опыт прошлого и перспективы на будущее // Наш трудный путь к праву: Материалы философско-правовых чтений памяти академика В.С. Нерсесянца - М., 2006.

3. Четвернин В.А. Современные концепции естественного права. - М.: Наука, 1988.

4. Честнов И.Л. Диалогическая онтология права в ситуации постмодерна // Известия вузов. Правоведение. 2001.— № 3.—C. 45-46

( ) Каландаришвили Зураб Нодарович ( zurab.kalandarishvili@yandex.ru ), Kуренков Герасим Алексеевич ( kurencov.spb@gmail.com ).

Журнал «Современная наука: актуальные проблемы теории и практики»

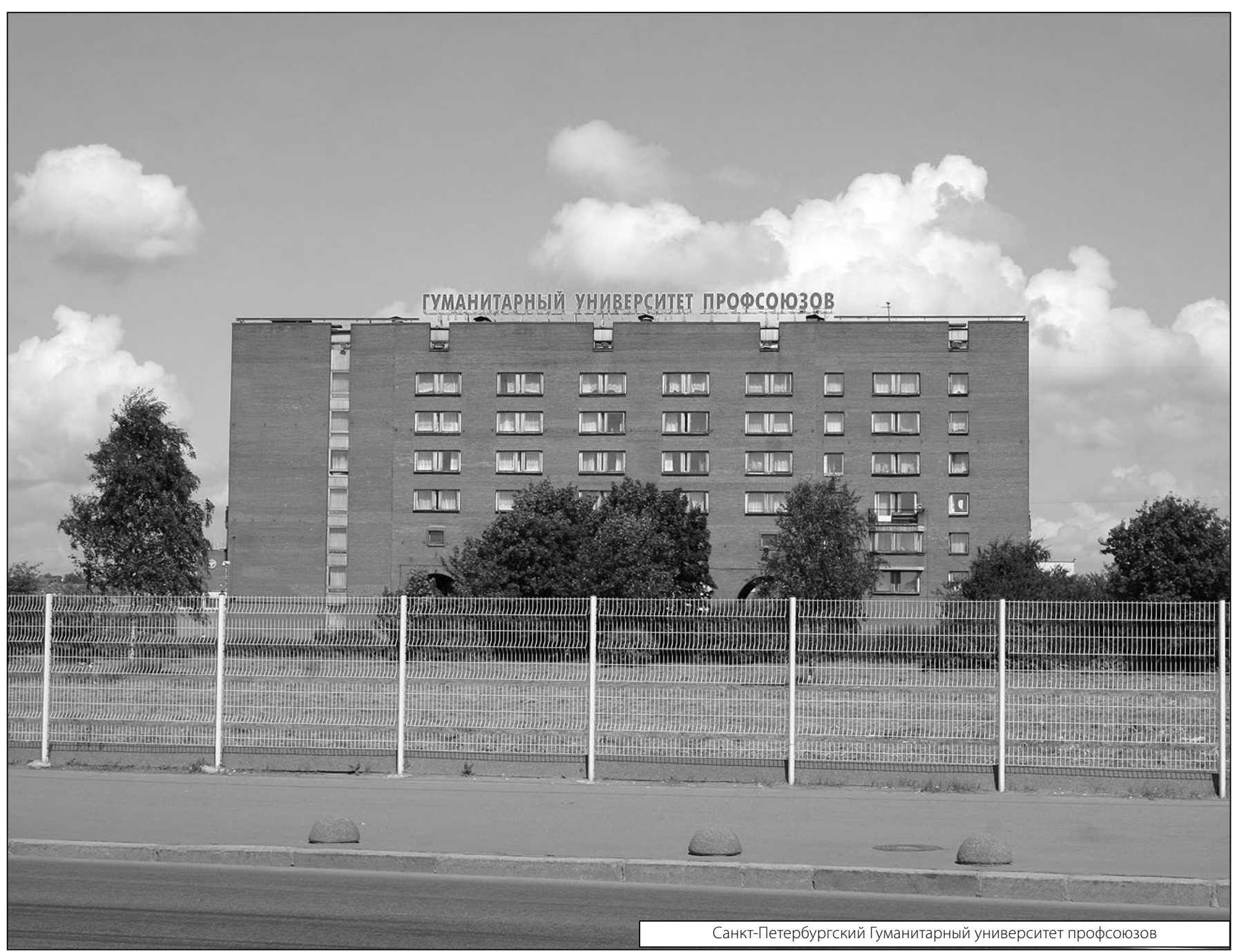

